\title{
Використання ВЧ-електрозварювання при лапароскопічній холецистектомії з причини гострого холециститу, ускладненого паравезикальним інфільтратом
}

\author{
M. YU. NYCHYTAYLO, A. I. HUTSULIAK, I. I. BULYK, I. V. DYBENKO \\ O. Shalimov National Institute of Surgery and Transplantology
}

\section{USING HIGH-FREQUENCY ELECTRIC WELDING METHOD DURING LAPAROSCOPIC CHOLECYSTECTOMY BY REASON OF ACUTE CHOLECYSTITIS COMPLICATED BY PARAVESICAL INFILTRATE}

\begin{abstract}
У 20 хворих із гострим калькульозним холециститом, ускладненим паравезикальним інфільтратом, під час виконання лапароскопічної холецистектомії для дисекції тканин та гемостазу використовували метод високочастотного електрозварювання. Застосування даного методу при дисекції дозволило значно зменшити кровоточивість інфільтрованих тканин за рахунок того, що відбувалося заварювання всіх дрібних судин та капілярів і розсічені тканини майже не кровоточили. У випадках виникнення кровотечі метод ВЧ-електрозварювання, на відміну від монополярної коагуляції, дозволяє проводити гемостаз без постійного осушення операційного поля. Крім того, даний метод дає можливість проводити гемостаз як із дрібних капілярів, так і з судин більш великого діаметра, в тому числі з міхурової артерії. У результаті використання ВЧ-електрозварювання вдалося полегшити дисекцію тканин, покращити ідентифікацію структур зони трикутника Кало та значно скоротити час операції.

In 20 patients with acute calculous cholecystitis complicated with paravesical infiltrate when performing laparoscopic cholecystectomy using high-frequency electric welding method was used for tissue dissection and hemostasis. Dissection from using this method leads to welding of all small vessels and bleeding from inflammation tissue was significantly reduced. Highfrequency electric welding method in cases of bleeding opposed to monopolar coagulation allows hemostasis without permanent drying operation field. Also, this method enables hemostasis, both small capillaries and vessels with a larger diameter, including cystic artery. As a result of the use of HF-electric welding was able to facilitate tissue dissection, to improve identification of structures Kahlo triangle area and significantly reduce time operation.
\end{abstract}

Постановка проблеми і аналіз останніх досліджень та публікацій. На сьогодні лапароскопічна холецистектомія - це рутинний загальноприйнятий метод лікування жовчнокам'яної хвороби та інших захворювань жовчного міхура. Проте з поширенням лапароскопічної хірургії значно зросла частота таких тяжких ускладнень, як пошкодження жовчовивідних проток (ПЖП). Так, якщо в долапароскопічну еру ПЖП спостерігали в 0,2-0,3 \% хворих, оперованих з приводу холециститу, то з появою лапароскопії частота ПЖП зросла до 0,4-1,3%. Ранні дослідження пов'язували таке збільшення в основному з недостатнім досвідом хірургів, але навіть після проходження хірургами так званої “кривої навчання” частота ПЖП тримається на рівні 0,5 \%, без тенденції до зменшення [1, 2, 3, 4].

Головними причинами виникнення ПЖП є зміни в анатомії та неправильна інтерпретація струк- тур трикутника Кало. Найчастіше дані труднощі виникають на фоні гострого калькульозного холециститу, ускладненого паравезикальним інфільтратом. Внаслідок запальних явищ виникає не тільки потовщення стінок жовчного міхура, але і значно зростає їх кровоточивість при дисекції. Зміна типового розміщення анатомічних структур внаслідок запальної інфільтрації тканин та погана їх візуалізація через підвищену кровоточивість і призводить до помилок при ідентифікації міхурової протоки та артерії. Це, в свою чергу, стає причиною пошкодження структур гепатодуоденальної зв’язки [5, 6, 7].

Мета роботи: удосконалити техніку операційного лікування гострого калькульозного холециститу, ускладненого паравезикальним інфільтратом.

Матеріали і методи. Клінічне дослідження було проведено у 20 хворих із гострим каль- 


\section{З ДОСВІДУ РОБОТИ}

кульозним холециститом, ускладненим паравезикальним інфільтратом, які склали основну групу. В даній групі під час виконання лапароскопічної холецистектомії для дисекції тканин та гемостазу використовували метод високочастотного (ВЧ) електрозварювання. ВЧ-електрозварювання проводили апаратом Патонмед-ЕКВЗ-300 за допомогою спеціального біполярного лапароскопічного дисектора з мідними робочими поверхнями. Групу порівняння склали 20 хворих з аналогічною патологією, яким дисекцію та гемостаз проводили загальноприйнятими методами.

В основній групі, після стандартного встановлення 4-х троакарів та проведення огляду черевної порожнини, роз'єднання паравезикального інфільтрату проводили методом ВЧ-електрозварювання в режимах “Різання” та “Коагуляція”. Після ідентифікації шийки жовчного міхура (ЖМ) та гепатодуоденальної зв’язки виділення кишені Гартмана та дисекцію тканин в трикутнику Кало проводили як звичайним діатермічним гачком, так і зварювальним дисектором. Виділені міхурові артерію і протоку заварювали в режимі “Автоматичне зварювання”, а на куксу міхурової протоки проксимальніше 3-4 мм від завареного краю для страховки накладали кліпс. Кліпування а. cystica, а також дистальної кукси d. cysticus не проводили. Подальше виділення ЖМ з печінкового ложа проводили в основному методом ВЧ-електрозварювання в режимі “Різання”. Якщо після видалення ЖМ виникала потреба в додатковому гемостазі, то його також проводили методом ВЧ-електрозварювання в режимі “Коагуляція”. Операцію завершували встановленням у правий підпечінковий простір трубчастого дренажу діаметром 6-8 мм.

Результати досліджень та їх обговорення. Дисекція інфільтрованих тканин методом ВЧ-електрозварювання, після нетривалого набуття навичок, не складала технічних труднощів і майже не відрізнялася за швидкістю від дисекції за допомогою гачка. Використання ВЧ-електрозварювання при дисекції дозволило значно зменшити кровоточивість інфільтрованих тканин, у 70 \% випадків операція взагалі відбулася майже безкровно. Досягти цього вдалося внаслідок того, що під час дисекції відбувалося заварювання всіх дрібних судин та капілярів і розсічені тканини майже не кровоточили. Додатково окремо проводили заварювання як ідентифікованих судин, так і превентивно ділянок можливого їх розміщення. Але навіть якщо і виникала кровотеча, то метод ВЧ-електрозварювання дозволяв її зупинити значно швидше, ніж звичайну монополярну коагуляцію. Як- що при коагуляції гачком чи лопаткою потрібно постійно осушувати операційне поле, що в багатьох випадках потребує неодноразової зміни інструментів (відсмоктувача та гачка), то при використанні ВЧ-електрозварювання достатньо один раз ідентифікувати джерело кровотечі. В подальшому гемостаз можна проводити без евакуації витеклої крові, метод ВЧ-електрозварювання дозволяє працювати в воді та біологічних рідинах. За рахунок того, що високочастотний електрострум проходить тільки між робочими поверхнями інструмента, не відбувається його “пробій” у рідині, і можна не переживати, що виникне електротравма навколишніх тканин та органів. Ще одним важливим моментом, який дозволяє пришвидшити гемостаз, є те, що при використанні типової монополярної коагуляції навіть при наявності незначної кількості витеклої крові в ній відбувається розсіювання енергії і гемостаз малоефективний. При використанні ВЧ-електрозварювання розсіювання енергії майже не відбувається і гемостаз однаково легко проводити як при незначній, так i при вираженій кровотечі. Таким чином, використання ВЧ-електрозварювання дозволило практично мінімізувати крововтрату і проводити швидкий та ефективний гемостаз при виникненні кровотечі, що, в свою чергу, привело до зменшення часу операції. Так, якщо в групі порівняння середня тривалість операції становила 2 год 12 хв, то в основній - 1 год 44 хв, що майже на півгодини менше.

Крім того, більш ефективний інтраопераційний гемостаз дозволив покращити перебіг післяопераційного періоду. Так, в основній групі в післяопераційному періоді виділення через дренаж були мінімальні і в більшості випадків мали серозний характер із незначними геморагічними домішками. Виділення жовчі і свіжої крові в жодного хворого не спостерігали. Це дозволило в 8-ми випадках видалити дренаж вже на наступний після операції день (1-ша післяопераційна доба), ще в 10-ти хворих дренаж видалили на 2-гу післяопераційну добу і лише в 2-х на 3-тю. Водночас у групі порівняння в післяопераційному періоді виділення через дренажну трубку були значніше вираженими і особливо в 1-й день мали більш геморагічний характер. Гострої кровотечі теж в жодному випадку зафіксовано не було. В одного хворого мала місце помірна жовчотеча (близько 100 мл на добу), яка самостійно зупинилася на 4-й день - розцінено як жовчотечу з ходів Люшка. У зв’язку з більш вираженими виділеннями в групі порівняння на наступний день після операції дренаж було забрано лише у 2-х хворих, на 2-гу післяопераційну добу в 10-ти, на 3-тю у 6-ти, ще в 
одного - на 4-ту та у хворого $з$ жовчотечею - на 5-ту післяопераційну добу.

Пошкодження позапечінкових жовчовивідних проток та інших структур гепатодуоденальної зв'язки в жодного хворого як основної групи, так i групи порівняння зафіксовано не було.

Висновки. 1. Використання методу ВЧ-електрозварювання при лапароскопічній холецистектомії у випадках ускладнення гострого холециститу паравезикальним інфільтратом дозволяє проводити дисекцію тканин та заварювання як дрібних

\section{СПИСОК ЛІТЕРАТУРИ}

1. Bile duct injury during cholecystectomy and survival in Medicare beneficiaries / D. R. Flum, A. Cheadle, C. Prela [et al.] // JAMA. - 2003. - Vol. 290, № 16. - P. 2168-2173.

2. Referral pattern and timing of repair are risk factors for complications after reconstructive surgery for bile duct injury / P. R. de Reuver, I. Grossmann, O. R. Busch [et al.] // Ann Surg. 2007. - Vol. 245, № 5. - P. 763-770.

3. Bile duct injuries during open and laparoscopic choleystectomy in the laparoscopic era: alarming trends / J. Karvonen, P. Salminen, J. M. Grönroos // Surg Endosc. - 2011. - Vol. 25, № 9. - P. 2906-2910. судин, так і міхурової артерії, а також додаткових жовчних проток ложа жовчного міхура.

2. Проведення гемостазу методом ВЧ-електрозварювання $є$ швидшим та ефективнішим, ніж за допомогою монополярної коагуляції.

3. Майже повна відсутність під час операції кровоточивості тканин покращує візуалізацію та ідентифікацію структур трикутника Кало, чим попереджає травмування трубчастих структур.

4. Використання ВЧ-електрозварювання скорочує час, необхідний для проведення операції, та пришвидшує перебіг післяопераційного періоду.

4. Buturovic S. Iatrogenic injury to the common bile duct / S. Buturovic // Med Arch. - 2014. - Vol. 68, № 4. - P. 291-293. 5. Ничитайло М. Е. Повреждения желчных протоков при холецистэктомии и их последствия / М. Е. Ничитайло, А. В. Скумс. - К. : Макком, 2006. - 344 с.

6. Reconstruction of major bile duct injuries after laparoscopic cholecystectomy / K. Holte, L. Bardram, A. Wettergren, A. Rasmussen // Dan. Med. Bul. - 2010. - Vol. 57, № 2. - P. 413 - 415. 7. Blumgart`s Surgery of the liver, biliary tract and pancreas / L. H. Blumgart, W. R. Jarnagin, J. Belghiti [et al.]. - Philadelphia : Elsevier saunders. - 5th edition, 2012. - 2021 p. 